\title{
The Domination of a Fussy Strongman in Provincial Thailand: The Case of Banharn Silpa-archa in Suphanburi
}

\author{
Yoshinori Nishizaki
}

\begin{abstract}
Several scholars portray Thai provincial strongmen as having character traits associated with nakleng - 'tough guys' - who are violent and ruthless toward enemies, but generous and compassionate toward supporters. Banharn Silpa-archa, the strongman of Suphanburi province, does not fit the description however. His personality is reflected in the way he meticulously - fussily - monitors all local development projects. This surveillance pushes otherwise lazy and inefficient local civil servants to be more diligent in their work. Banharn's domination rests on Suphanburians' appreciation of his non-nakleng-type leadership.
\end{abstract}

One consequence of democratization in post-1973 Thailand has been the political prominence of allegedly corrupt provincial bosses, including violence-prone godfathers (chao pho). Several leading scholars of provincial Thai politics, such as James Ockey, Pasuk Phongpaichit and Chris Baker, portray many of these strongmen as having a set of common personality traits that are associated with nakleng. Variously translated into English as rowdy, rascal, tough guy, rogue and scoundrel, nakleng refers to men who are violent, brutal, masculine, bossy, fearless, abrasive, belligerent, ruthless, hedonistic and law-breaking, yet at the same time generous, compassionate, bighearted, loyal, caring and protective towards their supporters. ${ }^{1}$ Possessing these characteristics, the provincial bosses are believed to have established and maintained their domination by killing or cowing their enemies and by offering (extra-legal) protection to their vulnerable

Yoshinori Nishizaki is a Postdoctoral Fellow in the Southeast Asian Studies Programme at the National University of Singapore. He may be contacted at: seany@nus.edu.sg.

1 See James Ockey, 'Business leaders, gangsters, and the middle class: Social groups and civilian rule in Thailand' (Ph.D. diss., Cornell University, 1992); Ockey, 'Chaopho: Capital accumulation and social welfare in Thailand', Crossroads, 8, 1 (1993): 48-77; Ockey, 'The rise of local power in Thailand: Provincial crime, elections and the bureaucracy', in Money and power in provincial Thailand, ed. Ruth McVey (Singapore: ISEAS, 2000), pp. 80-3; Ockey, Making democracy: Leadership, class, gender, and political participation in Thailand (Honolulu: University of Hawaii Press, 2004); Pasuk Phongpaichit and Chris Baker, 'Chao Sua, Chao Pho, Chao Thi: Lords of Thailand's transition', in Money and power, ed. McVey, pp. 36-41; Sombat Chantornvong, 'Local godfathers in Thai politics', in Money and power, ed. McVey, pp. 53-73; Pasuk Phongpaichit and Sungsidh Piriyarangsan, Corruption and democracy in Thailand (Chiang Mai: Silkworm Books, 1996), pp. 57-107. For a work which has profoundly influenced these works, see Benedict Anderson, 'Murder and progress in modern Siam', New Left Review, 181 (May/June 1990): 33-48. As an aside, a nakleng's attributes are similar to the notions of virtu that Machiavelli discussed in The prince. 
followers from exploitative outsiders, such as tax collectors. What enables the strongmen to exercise such nakleng-type leadership successfully is the insufficient rule of law enforced by the central state in provincial Thailand. ${ }^{2}$ These descriptions (implicitly) evoke the image of what the late O. W. Wolters called 'men of prowess' with 'soul stuff, who are presumed to have been the most prominent leaders in Southeast Asia for centuries. $^{3}$

Some provincial strongmen, however, do not fit the prevailing description. This paper focuses on one such strongman: Banharn Silpa-archa, a veteran Sino-Thai Member of Parliament (hereafter MP) since 1976 from the agrarian province of Suphanburi. He has enjoyed unchallenged domination in Suphanburi; in every election he has contested, he has won by a landslide, receiving 60-90 per cent of the votes cast. Since 1994, he has been the leader of the Chart Thai Party (hereafter CT Party), one of the oldest parties in Thailand. Between 1995 and 1996, he even served as Prime Minister. Throughout this seemingly distinguished career, however, Banharn has been implicated in numerous corruption scandals. Accordingly, Thais in general call him all sorts of pejorative names, such as 'Mr ATM', portraying him as a politician who dispenses dirty money under the table to anyone who needs it. His short-lived yet highly inept administration is also believed to have paved the way for the economic crisis of 1997. Thus, conventional wisdom has it that Banharn is one of the many allegedly crooked provincial bosses whose rise to power has marked and hindered the process of post-1973 democratization. Indeed, Ockey pigeonholes Banharn as a nakleng. ${ }^{4}$

Banharn actually has few attributes of a nakleng. For example, he has never killed or threatened to kill any of his rivals; his election campaigns are remarkably free from grisly violence, intimidation and other seedy tools of domination associated with nakleng. Thus, even one of the most salient characteristics of nakleng, the violent nature, does not apply to Banharn. He is known locally for his generosity, but this similarity is about all he shares with nakleng-type strongmen. Generosity, however, is not the only quintessential trait of nakleng. An in-depth examination of Banharn's governing style in Suphanburi reveals that he is actually a very different type of leader. We cannot dismiss him facilely as a nakleng, as does Ockey on the basis of popular accounts or images of him depicted in Bangkok-based newspapers and other secondary sources.

By highlighting his most notable non-nakleng quality - his meticulousness or fussiness - this article will explain why Banharn commands popular support from ordinary Suphanburians. Unlike the prototype of nakleng-type provincial strongmen, Banharn pays inordinately punctilious attention to small details. A Chinese word that is often used to describe his character is longju (廊主). Derived from the Teochew dialect, longju means a shop-owner or manager in general. The word, however, is often used to imply a somewhat more specific and traditional type of owner or manager who directly and personally controlled everything and everyone in his shop in the pre-modern era. In an era when there was no functional specialisation of duties, a shop-owner naturally

2 See, for instance, Ruth McVey, 'Of greed and violence and other signs of progress,' in McVey ed., Money and power, p. 8, where she writes: 'Justice and protection were not to be found in government and the law but in personal relationships, and local leaders were looked to for this.' See also David Johnston, 'Bandit, nakleng, and peasant in rural Thai society', Contributions to Asian Studies, 15 (1980): 90-101.

3 O. W. Wolters, History, culture, and region in Southeast Asian perspectives (Ithaca: Cornell University Southeast Asia Studies Program, 1999), pp. 18, 94.

4 James Ockey, 'Thai society and patterns of political leadership', Asian Survey, 36, 4 (1996): 353. 
assumed such all-encompassing responsibility. ${ }^{5}$ Banharn, the son of a Teochew petty merchant who grew up in Suphanburi before the provincial economy started modernizing in the late 1980s, epitomizes a longju. ${ }^{6} \mathrm{He}$ displays a marked propensity to control everything that concerns him in Suphanburi, his provincial 'shop'. His control is so thorough that many Suphanburians refer to their own province as 'Banharn-buri', in which he calls all the shots. ${ }^{7}$ For many Suphanburians, especially Sino-Thais, Banharn and longju are synonymous. It is indeed Banharn's meticulous leadership that has popularized the word. ${ }^{8}$

Banharn's all-controlling and meticulous nature is most vividly manifested in the way he tightly monitors all local development projects from implementation to completion. Given this close surveillance, local civil servants - whom ordinary Suphanburians have traditionally perceived as callous, corrupt, tardy, inefficient and irresponsible are made to work very efficiently in the interest of local development. Banharn's unchallenged local domination rests, in good part, on ordinary Suphanburians' deep appreciation of this tight control and mobilization of civil servants.

To support this argument, I will focus on four aspects of Banharn's rise and leadership style. First, I show the historical circumstances under which Banharn's leadership appeared and has come to be appreciated by ordinary Suphanburians. Specifically, I spotlight the failure of the supposedly developmental state to develop the province in the 1960s-70s and the consequent negative images of local-level civil servants. To appreciate why many Suphanburians value Banharn's meticulousness the way they do, we must pay attention to this historical context. Secondly, I describe the broad institutional factors, such as the persistence of patrimonial practices in the current democratic state, which have allowed Banharn to exercise his leadership effectively since 1976. Political scientists uniformly cast patrimonialism in a negative light, but as far as Suphanburians are concerned, it is a boon that has ushered in the rise of Banharn's leadership. Thirdly, I discuss how Banharn controls local civil servants by focusing on two concrete means of control: the inspection of development works and the holding of meetings. Lastly, I analyse the positive effects of Banharn's leadership for ordinary Suphanburians. I show how various public development projects have been provided efficiently due to his close supervision of local civil servants. This article is not meant to be an unabashed panegyric of Banharn's achievements in Suphanburi, let alone an apology for his alleged

5 Takejiro Tomita, Tai-Nichi jiten [Thai-Japanese dictionary] (Tenri: Yotokusha, 1990), p. 1917; 「世界華僑華人詞典. [Dictionary of Overseas Chinese] (Beijing: Beijing University Press, 1993), p. 47. I thank all my (Sino-)Thai informants who have educated me on the meaning and nuances of this word. Pasuk and Sungsidh translate the word as 'an executive manager' (Corruption and democracy, p. 104), but this translation may be a bit misleading because it connotes a modern type of manager in modern society.

6 Banharn's father, Saeng Kim Be, migrated to Thailand in 1907 and ran a small shop dealing in Buddhist ornaments, clothes and daily consumables in the central market town of Suphanburi; Akharaphon et al. Senthang suu Nayok Ratamontri khong tueng siao harn Banharn Silpa-archa [Banharn Silpa-archa's road to the Premiership] (Bangkok: Nam Fon, 1995), p. 18; my interviews with Sino-Thai local merchants in Suphanburi in 2002 and 2004.

7 The suffix 'buri' means 'town'. 'Banharn-buri' thus means 'Banharn's Town'. Bangkokians use this phrase to criticize Banharn for having turned Suphanburi into his personal fiefdom. When used by Suphanburians, however, the term carries a more positive connotation.

8 On comparing Banharn to a longju, see Nikhon Chamnong, Boriharn ngan satai Banharn [Banharnstyle management] (Bangkok: Mathichon, 2000). 
corruption. The aim is to analyse why Banharn continues to receive support in Suphanburi despite a period of failure as a politician at the national level.

\section{Images of state officials at the local level}

In the minds of people living in the countryside, the 'state' is little more than a distant, abstract, amorphous and invisible urban Goliath located in, and associated with, the capital city where 'big shots' make important decisions. Yet, at the same time, 'the state' is vividly represented in the eyes, ears and bodies of local people. Local people construct or imagine 'the state' upwards on the basis of what they hear, see and (are made to) do in their daily lives and interactions with its rank-and-file agents. The otherwise intangible 'state' consists of various images created by the concrete behaviour, practices and words of local-level officials. ${ }^{9}$ In provincial Thailand, these images have not been very positive. Provincial Thais have traditionally regarded state officials as displaying a set of undesirable characteristics. Suphanburians are among the many who have held civil servants in such low regard.

Suphanburians' negative perceptions have long historical roots, but they were likely reinforced during the 1950s-70s, the heyday of the 'bureaucratic polity' in which civilian and military bureaucrats held monopolistic power. ${ }^{10}$ During these decades, the supposedly 'developmental' authoritarian state led by Field Marshal Sarit Thanarat (1958-63) and General Thanom Kittikachorn (1963-73) undertook massive rural infrastructure development (among other things) with hefty financial support from the United States and the World Bank. Rhetoric to the contrary, however, the 'developmental' state was conspicuous for its relative absence in Suphanburi. There was a yawning gap between what the state publicly trumpeted and what it actually did. This gap led many Suphanburians to become quite cynical when dealing with state officials.

From the 1950s to the 1970s Suphanburians regarded officials as inattentive to their developmental needs. This image grew since the supposedly 'cash-awash' state failed to allocate sufficient developmental funds for Suphanburi. To compensate for scarce state funds, villagers had to carry out their own development projects. Between 1962 and 1976, for example, villagers in various parts of the province undertook numerous road construction/repair projects by using their own simple tools and money. Villagers had to undertake these works despite the fact that the state accorded 'top priority' to road construction. ${ }^{11}$ The construction of an unsurfaced road, 156 metres in length and one metre in width, in Don Tal sub-district in 1974 is illustrative (Figure 1). ${ }^{12}$ The former village head, now over 80 years old, used one pithy sentence to recount the circumstances under

9 See Timothy Mitchell, Colonising Egypt (Berkeley: University of California Press, 1991); Joel Migdal, State in society: Studying how states and societies transform and constitute one another (Cambridge: Cambridge University Press, 2001), pp. 15-23; and Akhil Gupta, 'Blurred boundaries: The discourse of corruption, the culture of politics, and the imagined state', American Ethnologist, 22, 2 (1995): 375-402.

10 Fred Riggs, Thailand: The modernization of a bureaucratic polity (Honolulu: East-West Center Press, 1966).

11 National Economic Development Board (hereafter NEDB), The national economic development plan, 1961-1966: Second phase, 1964-1966 (Bangkok: 1964), p. 107.

12 Khon Suphan (hereafter KS), 10 June 1974. For accounts of other such works, see KS, 30 Apr. 1962; 15 May 1962; 30 Oct. 1962; 30 May 1963; 5 July 1963; 25 Dec. 1963; 20 May 1968; 20 Sept. 1968; 10 Jan. 1970; 10 June 1971; 30 July 1973; 10 Sept. 1973; 30 Nov. 1973; 10 June 1974; 20 June 1974; 20 July 1974; and 10 Dec. 1974. Khon Suphan is the oldest provincial newspaper in Suphanburi and has been published since 1957. 


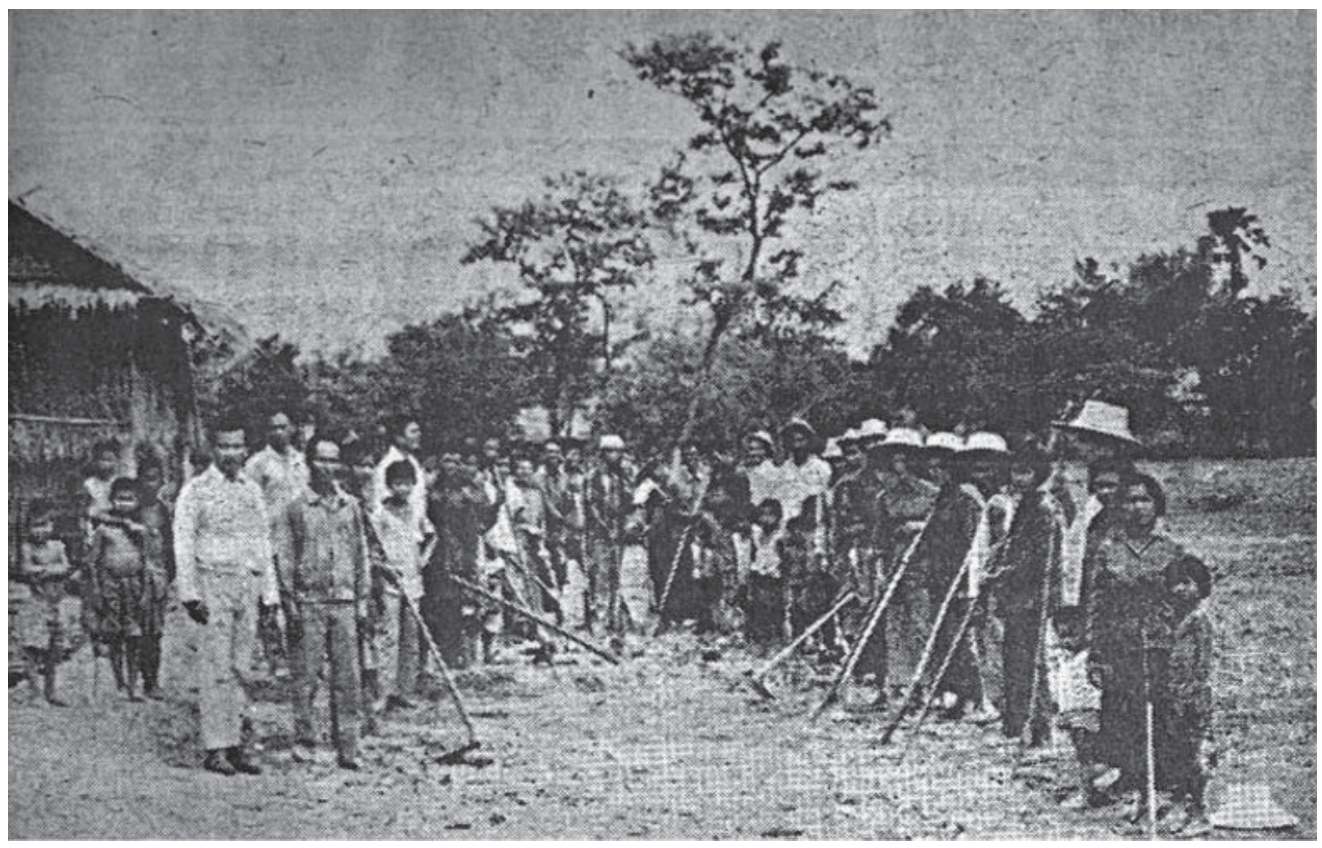

Figure 1 Suphanburi's villagers building a road on their own with simple tools

Source: KS, 10 June 1974.

which he was compelled to mobilize his villagers to build this short road: 'ngop mai thueng' (The budget [of the state] didn't reach us). He elaborated on the unresponsive and tight-fisted nature of the 'developmental' state and its officials as follows:

Back then, there was no road at all around here. So, villagers had lots of trouble even just going to the market to buy and sell things. So they asked me again and again to do something about it. I contacted the District Office several times to ask for funds [for road construction]. Each time I was told, 'The budget isn't sufficient.' I said, 'No sufficient budget? I heard that the province got several million baht for local development. Why not give our village some of it?' Their answer was, 'We decide how the money is used.' So, in the end I gave up, and I went around the village, asking people: 'If they aren't going to build a road for us, why not do it on our own?' Most people agreed because a road was so important to us. So, people around here took turns to help build a road together. It was very tiring. ${ }^{13}$

Stories of other development works implemented by villagers abound. In 1968, for instance, 400 villagers in Nong Ya Sai sub-district dug a 20-kilometre irrigation ditch together. In the same year, villagers in another sub-district, Kho Kho Tao, built a primary school classroom 'without any budgetary assistance from the state'. ${ }^{14}$ While the second National Economic Development Plan (1967-71) increased expenditures for education

13 Interview, 18 Feb. 2002.

14 For articles on irrigation duct construction, see KS, 10 Sept. 1968; 5 Apr. 1962; 14 Mar. 1967; 28 June 1968; 28 Feb. 1970; and 20 June 1972. For articles on school construction, see KS, 20 June 1968; 4 Apr. 1967. 
by some four per cent from the first plan, the funds apparently failed to reach Suphanburi. ${ }^{15}$

These public works were collective endeavours involving almost everyone in a given local community. A good case in point was the construction of a three-kilometre road in Don Kam Yan sub-district of Muang district in May 1968. The sub-district chief mobilized some 1,000 villagers, including women and children, for this work. Wealthy villagers supplied a grader and three tractors. Those who did not engage in physical labour, presumably the sick and the old, cooked lunch and served it to the labourers. The construction expense of 20,000 baht came from the villagers' own pockets. ${ }^{16}$

It would be a mistake to interpret all these local development works as indicating villagers' time-honoured norms of self-reliance, mutual help and public spiritedness and the consequent superfluity of the modern intrusive state. ${ }^{17}$ Stories of villagers working together for the benefit of their community are often romanticised, not taking into consideration the sheer amount of time, energy and material resources required of villagers. To give but one example, the construction of a road, 2.5 kilometres in length and four metres in width, in Pho Phraya sub-district of Muang district took 20 years to complete.$^{18}$ Knowing how onerous all the development works were, a columnist for Khon Suphan newspaper, in reporting on the villagers building a small bridge in U-Thong district with their clothes and faces dirtied with mud and sweat, exhorted 'big shots in Bangkok' to 'come and dig together with these villagers to accumulate (Buddhist) merit'. ${ }^{19}$ If villagers in Suphanburi 'volunteered' to carry out development works on their own, it is only because state officials were not fulfilling their duty, thus placing the burden of rural development on the villagers. ${ }^{20}$

One major cause of the shortage of funds at the local level was corruption, which pervaded the 'developmental' state. In fact, with the latters advent, state corruption, nothing new to most Thais, may have reached epidemic proportions. After Sarit died in 1963, for instance, the media disclosed, to the consternation of provincial Thais, that he had acquired an astronomical \$410 million and 8,000 acres of land in just five years in office. ${ }^{21}$ After Sarit's death, corruption continued unabated, involving, in particular, the

15 NEDB, The second national economic and social development plan 1967-71 (Bangkok: 1967), p. 195.

16 KS, 20 May 1968.

17 Chatthip Nartsupha, The Thai village economy in the past (Bangkok: Silkworm Books, 1997); James Scott, The moral economy of the peasant (New Haven: Yale University Press, 1976).

$18 K S, 10$ June 1971.

19 KS, 10 May 1973. A study conducted in another Thai province, Khon Kaen, lends additional support to my interpretation. The study found that, while supporting development in principle, many villagers do not want to sacrifice their own precious time and money for it. Plainly stated, they want development, but not if they have to contribute to it - a finding that supports Samuel Popkin's assumption derived from economics; Ratana Boonmathya, 'Contested concepts of development in rural Northeastern Thailand' (Ph.D. diss., University of Washington, 1997), pp. 69-70, 146-9.

20 This was not confined to Suphanburi alone. Philip Hirsch, for example, shows that in neighbouring Uthai Thani province, villagers cooperated to build simple roads together. In Phetchabun province, too, villagers carried out development works on their own without receiving any state funds; Philip Hirsch, Development dilemmas in rural Thailand (Singapore: Oxford University Press, 1990), pp. 171-2; Provincial Office of Phetchabun, Rai-ngan kitjakan prachampii 2503 [Report of activities, fiscal year 1960] and Rai-ngan kitjakan prachampii 2506 [Report of activities, fiscal year 1963].

21 Thak Chaloemtiarana, Thailand: The politics of despotic paternalism (Bangkok: Social Science Association of Thailand, 1979), p. 338; David Wyatt, Thailand: A short history (New Haven: Yale University Press, 1984), p. 285. 
powerful Ministry of Interior and its various departments, which are directly in charge of rural development. According to one statistic, 857 (56 per cent) of 1,542 corruption cases filed against all ministries between 1970 and 1972 involved the Interior Ministry. ${ }^{22}$ Between 1969 and 1971, when Thanom allowed Parliament to exist, many politicians, including Suphanburi's MP Bun-uea Prasertsuwan, exposed embarrassing cases of political corruption in their respective provinces, which prompted an irritated Thanom to stage a coup against his own government in November 1971 and abolish Parliament. ${ }^{23}$

Corruption had been a serious problem in Suphanburi since at least the late nineteenth century. When Minister of Interior Prince Damrong visited the province in 1892, for instance, villagers submitted 'countless petitions against misgovernment' to him. Damrong subsequently sacked Suphanburi's governor for corruption. Damrong also referred to the provincial nobility of Suphanburi as 'an assembly of crooks', who hampered the growth of effective local administration. The tradition of 'eating the state' (kin muang) persisted well into the twentieth century. ${ }^{24}$ In 1975, nearly a century after Damrong's visit, villagers in Sakaew sub-district of Muang district charged local officials with appropriating land taxes (which had been raised from three to five baht per rai, or 1,600 square metres) without using them for village development. Utterly fed up with the gravity of official corruption, these villagers even sent a letter of protest to Governor Sawat Meephian, expressing a desire to secede from the municipality in which their village was located. ${ }^{25}$

The exact extent of state corruption, of course, cannot be known, but the sensationally reported news about national-level corruption on a massive scale, coupled with the longstanding history of local-level corruption, led Suphanburians to create an adverse image of the state consisting of rapacious officials bent on 'devouring' development funds. A scenario of corruption that many villagers depict is that before state funds were channelled into Suphanburi, 'big men' in Bangkok took a first cut from them. As soon as the remaining funds reached the province, the Governor took a second cut, followed by deputy governors. When the rest of the funds were transferred to a lower department, its chief took an additional cut, followed again by his subordinates. As the funds went down the bureaucratic ladder, they were thus 'eaten' at each rung. By the time they reached the lowest village level, there was practically nothing left. My respondents do not have any concrete evidence of this pyramidal system of 'bureaucratic eating'; it is little more than what they had constructed in their heads. But, to the local people, the image is too 'real' to be refuted by logic, for it explains impeccably why they were chronically suffering from insufficient state funds and why they had to do development work without any.

When the state did allocate money, Suphanburians viewed state agents as exasperatingly inefficient, slow, irresponsible and desultory in fulfilling their duties. One good case in point concerns the maintenance of a big modern provincial athletic field with an eight-lane track, which the Department of Physical Education built in mid-1973 at a cost

22 Pasuk and Sungsidh, Corruption and democracy, p. 26.

23 David Morell, 'Power and parliament in Thailand: The futile challenge, 1968-1971' (Ph.D. diss., Princeton University, 1974), pp. 638-68.

24 Tej Bunnag, The provincial administration of Siam, 1892-1915 (Kuala Lumpur: Oxford University Press, 1977), pp. 100, 105, 167. On kin muang, see Pasuk and Sungsidh, Corruption and democracy, p. 7.

25 KS, 10 Sept. 1975. 
of 200,000 baht. At first, the Provincial Office showed much concern about the maintenance of this field in preparation for an annual provincial-level sports competition to be held there at the end of 1973. Given this maintenance work, Khon Suphan said with pride: 'We believe that from now on, the level of athletics in Suphanburi will get better and better.' ${ }^{26}$ These expectations turned out to be premature, however. For, once the scheduled competition was called off due to the student 'revolution' of October 1973 in Bangkok and the subsequent social unrest, the Provincial Office completely neglected its duty to keep the field in proper condition, leaving the lawn and weeds to grow 'thick and wild' (benja phan). When the reporter from Khon Suphan went to see the conditions in person, he had to 'spend a long time figuring out even where the track lanes were' because the weeds had covered the whole field. The reporter thus expressed his shock and disappointment that the Provincial Office had 'abandoned' the field like this for a long time, saying: 'It never occurred to me that our province would fail to take good care of its own athletic field.' 27

An even more revealing example concerns the construction by the Department of Highways of a 110-kilometre highway between Suphanburi and Chainat, a province situated to the north. During his visit to Suphanburi in 1967, Prime Minister Thanom recognized the importance of this highway, and subsequently added it to the five-year highway construction plan (1965-69) by allocating a fund of 2,659,950 baht (nearly 50 per cent of which came from the World Bank). ${ }^{28}$ The highway was completed in 1970, but it was a sub-standard road made of laterite (or red earth), a construction material of the poorest quality. Within a year, the road became impassable due to severe damage caused by heavy vehicles. Bun-uea, Suphanburi's MP, consequently submitted a request to Thanom that the highway be asphalted. Thanom approved the request, and announced that the surfacing would be carried out in 1971 with another hefty World Bank loan of over 69 million baht. ${ }^{29}$ By mid-1971, however, the project had not begun. This led Suphanburians to suspect that 'the state has used the fund to build a road somewhere else that it regards as more important' ${ }^{30}$

Following the coup of 1971, many projects that had been approved the year before were frozen. The Suphanburi-Chainat highway was one of those projects. It was only in early 1973 that its construction got under way with another loan of 21.4 million baht. ${ }^{31}$ The government announced that the project would be completed in 1974. In mid-1974, however, the Highways Department announced that the construction would be delayed due to the rising prices of raw materials, which forced the state and the contractor, Hyundai of South Korea, to renegotiate the original budget. The negotiation fell through, however. Hyundai withdrew from the project in 1975, abandoning its ongoing construction work. The government therefore announced that it would choose a new contractor, but that the whole selection process would 'take another eight to ten months', showing

26 KS, 20 June and 30 July 1973.

27 KS, 30 Oct. 1974.

28 KS, 30 May 1968; NEDB, Development projects requiring financial assistance under the second plan (1967-1971) (Bangkok: 1968), p. 35.

29 KS, 30 October 1970 and 10 July 1973.

$30 \mathrm{KS}$, 10 June 1971.

31 KS, 20 Mar. 1973, 10 June 1973; Budget Bureau [hereafter BB], Ekasarn ngop-pramarn: ngop-pramarn prachampii ngop-pramarn 2518 [Budget document: Budget of fiscal year [hereafter EN] 1975], 3, 4: 159, 171. 
no sense of urgency in implementing the project. ${ }^{32}$ To make matters worse, local officials told a story that the project might be completed by the end of 1975, which Suphanburians dismissed as 'a placebo (ya horm) aimed to make them happy [temporarily]'. A local newspaper columnist therefore urged:

State officials in charge should not be sitting idle, showing no concern for, and being indifferent to, this project. Suphanburians have felt like this for a long time, but they just don't speak up.... If Hyundai has abandoned this work, let it be. We'd better get another company to do the work. And [the state should] do it quickly without dragging its feet (oi ying) like this forever. ${ }^{33}$

These (and many other) accounts show how the negative images of state officials were produced and reproduced in the eyes and minds of many Suphanburians. The 'developmental' state, when seen through the concrete actions and practices of its agents at the local level, fell short of doing what it publicly avowed to do or boasted as having achieved. Suphanburians therefore had only a limited trust in the ability, commitment and sincerity of state officials in undertaking local development. Official reports, which complacently praised the state-led development works as making 'satisfactory' or 'steady progress', ignore what was happening at the local level and how ordinary Suphanburians viewed the state and its agents. ${ }^{34}$ True, state-led rural development was not a total failure. For example, the state built over 9,000 kilometres of provincial highways between 1959 and $1974 .{ }^{35}$ On the basis of this kind of aggregate technical data at the national level, the 'developmental' state could claim success. Local accounts, which remain hidden behind dry official reports, suggest, however, that at the lowest village level, many Suphanburians perceived the state as doing relatively little. It is against this historical backdrop that they have come to appreciate the rise of Banharn's meticulous leadership in post-1976 Suphanburi.

\section{The fussy patron}

Banharn has ruled Suphanburi within an institutional milieu in which the (outwardly) democratic state continues to be fundamentally patrimonial in nature. Patrimonialism is characterized by a weak division between public and private spheres, and official power is regarded as personal property. This feature, one of the salient features of the Thai state in the authoritarian past, has persisted into the current democratic period. ${ }^{36}$ Thus, power-holders continue to allocate scarce state resources in ways that benefit them personally. Banharn has been one such power-holder. Reflecting his high status in the influential CT Party, which he joined in 1976, Banharn has held many Cabinet posts, such as Minister of Agriculture, Minister of the Interior and Prime

32 KS, 10 Apr. 1975 and 20 May 1975.

33 KS, 10 Sept. 1974. For other cases that indicate bureaucratic inefficiency, see KS, 28 Dec. 1965; 3 Jan. 1967; 20 July 1969; 30 Aug. 1969; 20 Jan. 1971; 30 July 1971; and 20 Nov. 1971.

34 NEDB, The second national economic and social development plan, pp. 181, 190.

35 National Statistical Office, Statistical yearbook: Thailand, 24 (1963): 222 and 31 (1974-75): 293.

36 Riggs, Thailand; Norman Jacobs, Modernization without development: Thailand as an Asian case study (New York: Praeger, 1971). 
Minister. His family members and protégés have also held high positions. ${ }^{37}$ These posts have given Banharn enormous personal influence over bureaucratic posts and funds, both of which are allocated to great effect in a patrimonial state. The extent to which he wields this influence is not important; in the institutional context it is the perception of civil servants that matters.

The significance of this (imagined) appointive and budgetary power is that local civil servants in Suphanburi have come to be dependent on Banharn for promotions and/ or funds. They have accordingly come to see it in their best interests to appease him. Some civil servants do so out of fear that Banharn might demote/transfer them or slash funds as a punishment if they lack loyalty. The appointive and budgetary power rooted in the patrimonial state has enabled Banharn to acquire a huge web of bureaucratic clients extending from the Governor to village heads, whose behaviour he can tightly control as a longju-type administrator. To the extent that civil servants are interested in maximizing their chances of acquiring higher posts and state funds, they are driven to follow Banharn's leadership.

Banharn's control of civil servants has further increased since 1988, when Suphanburi emerged as a 'one-party dominant province'. Between 1988 and 1996, among the 75 provinces of Thailand, only one other province, Phang-nga, is under the control of one party, and only because it has only one MP. The significance of this phenomenon is twofold. First, with all the MPs of Suphanburi firmly under his control, Banharn has become the single conduit through which development funds flow into Suphanburi from the coffers of the state. Secondly, virtually all bureaucratic appointments in the province have come to reflect his personal wishes. Before 1988, civil servants in these could have hoped to obtain state funds and promotions by relying on politicians representing other parties. Since 1988, however, there has been no such alternative patron. This has rendered local civil servants completely dependent on Banharn, which in turn has enabled him to enforce his leadership all the more effectively.

Banharn's longju-style leadership is reflected, first and foremost, in his frequent and meticulous inspection of local development projects. He does not just channel development funds from the state; he also closely monitors how civil servants actually use those funds. If he has allocated money for renovating a school, for example, he frequently visits the school to check on the progress of the renovation and to ensure that civil servants (and contractors) are not cutting corners. He thus oversees every stage of a given project from implementation to completion. He does not trust local civil servants to work competently and efficiently on their own - a perception that many villagers share on the basis of their past experiences. He is a veritable longju who believes in the proverb: ' maew mai $y u$, nuu raa rerng' ('When the cat is away, mice will be happy'). ${ }^{38}$

37 Banharn's younger brother, Chumpol, served as Deputy Minister of Communication (1981-83) and minister of Education (1997-98), while his daughter, Kanchana, was Deputy Minister of Education (1999-2000). Three other MPs of Suphanburi have also held several Cabinet posts over the past two decades.

38 Several Suphanburians used this saying to describe Banharn's belief that guides his behaviour towards local civil servants. Examples of Banharn's inspection activities include the inspection, in January 1990, of the construction of a bridge and a riverside pavement in central Muang district. Once he finished this inspection, he quickly moved on to inspect road construction projects in two other sub-districts. Likewise, in October 1999, he spent the whole day inspecting the construction of six development works - three roads, one temple, and two schools - in five districts (KS, 1 Feb. 1990 and 16 Oct. 1999). 
Banharn does not inspect sites just once; he does so consistently over a long period of time until the construction is completed to his satisfaction. One notable example is the project he inaugurated in 1997 to develop a huge wild marsh (named Chawak Marsh) in Derm Bang Nang Buat district into a tourist attraction. In the course of implementing this project between 1998 and 2002, he inspected its progress 23 times. ${ }^{39}$ The same holds for the renovation of Khao Dee Salak Temple in U-Thong district. In the 1980s, the conditions of this temple, famous for Buddha's footprints that were supposedly left in the Dvaravati period, steadily deteriorated despite the effort of the Provincial Office. This prompted Banharn to initiate a major six-year renovation project in 1993. Once this project got under way, he inspected the ongoing renovation 14 times between 1993 and 1999. Even after the renovation was completed, he visited the temple six times to inspect its maintenance conditions. Similarly, throughout the process of building a four-story Provincial Hall between 1995 and 1999, Banharn inspected its construction every week. ${ }^{40}$

Another prominent feature of Banharn's inspections is that they often take place outside regular working hours, typically on Saturday and Sunday and sometimes before 8:00 a.m. or after 5:00 p.m. To give but one example, on 5 December 1995, the birthday of the revered King, then Prime Minister Banharn came to Suphanburi at 10:00 p.m. (after presiding over a televised grand jubilee in Bangkok) just to check the electric ornaments that had been put up at various intersections in honour of the King. Once satisfied with their condition, he returned to Bangkok at midnight. ${ }^{41}$

During any inspection, a wide range of provincial authorities, who are dependent on Banharn for promotions and state funds, make it a rule to accompany him. For example, when inspecting any primary school, he is always accompanied not only by its schoolmaster and teachers but also by village heads, the Heads of the Provincial Offices of Education, relevant District/Sub-District Chiefs and their respective subordinates. Almost invariably, the Governor, two Deputy Governors, and an Assistant Governor also accompany Banharn. Figure 2 shows one typical inspection, conducted at the aforementioned Khao Dee Salak Temple along with a long retinue of civil servants from the Provincial Offices of Archeology and Fine Arts, the U-Thong District Office, as well as others.

Banharn's behaviour during any of his routine inspection tours can best be described as 'meticulous' (la-iad) and 'thorough' ( rorp khorp). He checks the quality of an ongoing project very thoroughly with local civil servants and contractors by his side. Banharn has described the manner of his inspections as: 'I am very cautious and watchful. I won't allow any loophole. ${ }^{42}$ If he finds anything that he is not happy about, he scolds the officials in charge, pointing his fingers in their face - his characteristically domineering gesture, which many civil servants hate. Asiaweek reporters who followed

39 KS, 16 Mar., 16 May, 16 June, 1 July, 16 Nov. 1998; 1 Dec. 1999; 16 May, 1 Oct. 2000; 1 Mar., 2 May, 16 July, 16 Oct. 2001; 16 May, 16 Aug., 1 Nov., and 1 Dec. 2002. Suphan Post, 16 Apr., 16 Oct. 1999; 1 Jan., 16 Jan. and 1 Oct. 2002; unpublished news stories supplied by an informant.

40 Suphan Post, Dec. 2001 and 16 Aug. 1999 (Suphan Post, now called Isara, is a monthly provincial newspaper published since 2001); KS, 16 April 1993; 1 Nov., 30 Dec., 16 Nov. 1993; 16 July 1996; 16 Mar., 16 Sept. 1997; 16 June, 16 Aug., 30 Dec. 1998; 16 June, 1 July, 1 Aug. 2000; 1 Sept. 2001; 1 June, 16 Sept. 2002; Isara, June 2002; unpublished news stories supplied by an informant.

41 KS, 16 Dec. 1995.

42 KS, 1 March 1987. 


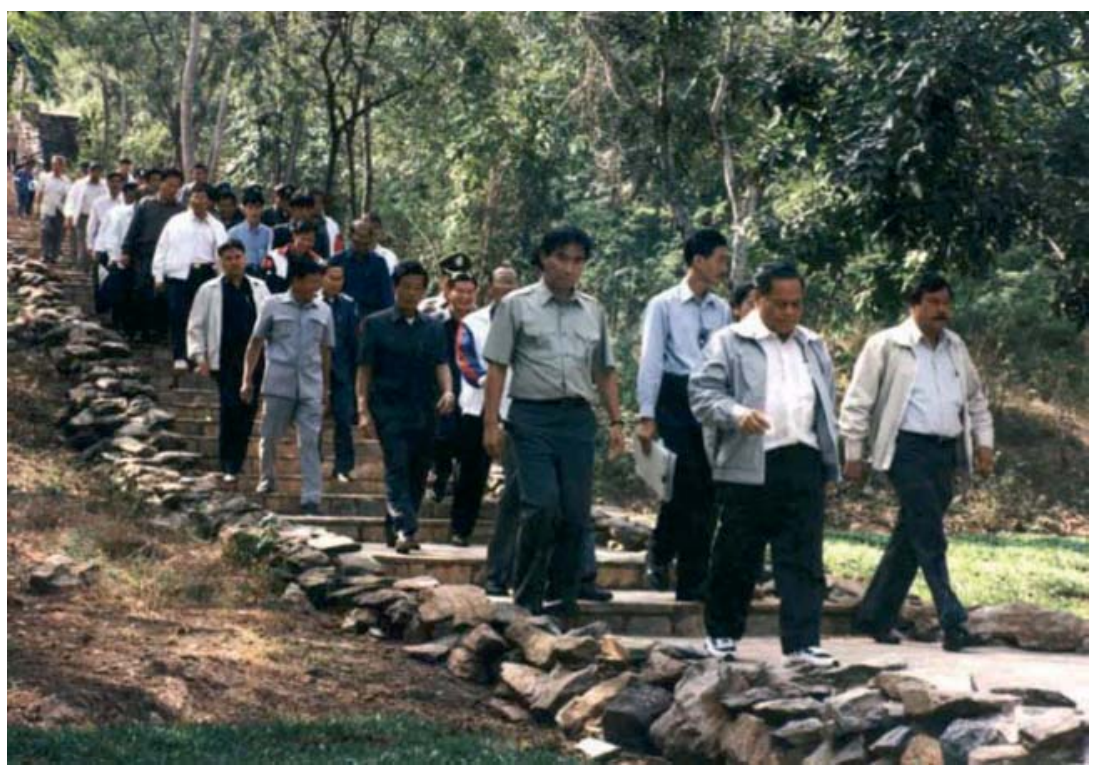

\section{Figure 2 Banharn inspecting the renovation of Khao Dee Salak Temple, 7 December 1998 (Photo courtesy of an informant)}

Banharn on one occasion saw him scuffing a road with a deep frown and berating an accompanying official from the Highways Department: 'Not enough cement has been used here. This is why I have to come personally and check all the details. I suggest you get this repaired. ${ }^{43}$ Banharn himself once described his role with regard to road construction as follows:

I am the acting [quality] control manager for the Highways Department.... I am very strict. I go and see everything on every road, whether they are levelling ground, pouring concrete, or laying wooden bases. If my car doesn't shake as it moves on the road, I let [the construction work] pass. If my car shakes, then I will have the contractor repair [the bad spot $].{ }^{44}$

Banharn also checks very carefully the aesthetic conditions of various public works in Suphanburi. In a manner that is reminiscent of Sarit, Banharn sees beauty, cleanliness and orderliness as signs of civilization, and he cannot stand the sight of dirt or disorder. For example, as he moves around from one construction site to another by car, he looks out the window to see if the flowers, trees and grass planted in the median strips of major

43 Asiaweek, 4 Feb. 2003, p. 28. The reporter also comments: 'Attention to detail is Banharn's forte. Ordering the changing of a lightbulb or chastising contractors over the quality of a varnished floor in a sparkling new basketball stadium is all in a weekend's work for the former premier.'

44 Chart Thai Samphan, 13 (2001): 17. On another occasion, he similarly described his character as follows: 'I watch everything - submitting a tender, buying rice, buying materials to be used in my business, or managing works in accordance with the target of the contract'; Khomduean Choetcharatfa, Cheewa prawat lae thasana Banharn Silpa-archa, Nayok Ratamontri khon thi 21 khong thai [The life and viewpoint of Banharn Silpa-archa, Thailand's 21st Prime Minister] (Bangkok: Soi Thong, 1995), p. 56. 
highways are in good condition. He takes note of anything that does not satisfy him, and demands that civil servants in charge take immediate attention. Also, if he spots any rubbish on the roads or in the median strips, he tells his driver to pull over, gets out of his car and picks up the rubbish with his bare hands. He then shows the rubbish to officials in charge and berates them for not maintaining the roads. Occasionally, he even walks along major highways, inspecting the maintenance conditions of literally hundreds of trees and flowers. ${ }^{45}$

Additionally, on the way to and from any construction site, Banharn sometimes makes a surprise visit to various schools and hospitals to check on their maintenance. As one schoolmaster said to me, 'Mr. Banharn doesn't need any special reason to visit our school or any other school. Suppose he is going from one district to another. He sees a school, and if he has enough time and feels like it, he tells the driver, "Let's stop by at that school for ten minutes". ${ }^{46}$ The thought or fear that Banharn could pop up at any time brings enormous pressure to bear on civil servants to take extremely good care of various public works.

Another manifestation of Banharn's meticulousness is his frequent meetings with local civil servants to ensure that all development projects are going smoothly. This is his second means of controlling and monitoring local civil servants. One example is a meeting he held in April 2002 to discuss a budget plan for the following year with the directors of the 11 public hospitals in Suphanburi. At this meeting, Banharn had each director justify each requested budget item, and explain to what extent the funds allocated in the previous year were used in accordance with the original plans. The directors were expected to give a satisfactory explanation for every question asked. A local newspaper reporter who took me to the meeting said: 'This is like an oral examination at a university, and it's a gruelling exam. It's not easy. But if you are a civil servant here, you must pass the exam. ${ }^{37}$

Another typical example concerns the aforementioned renovation of Khao Dee Salak Temple. In initiating this project, Banharn established three committees, and he became the self-appointed chairman of all three. A gamut of high-ranking civil servants in Suphanburi, ranging from the Governor, Deputy Governors and District Chiefs to the Heads of the Provincial Offices of Education, Fine Arts, and Archaeology, were appointed to these committees. ${ }^{48}$ Throughout the renovation, Banharn called and chaired meetings with these committee members every two months between April and November 1993, and then every month between November 1993 and 1999. At each of these meetings, he demanded verbal briefings and a written report on the type, prices and suppliers of construction materials ordered and used, the progress achieved in meeting the targeted schedule of renovation, the number and wages of workers employed, and so forth. ${ }^{49}$ Likewise, throughout the process of constructing the aforementioned Provincial Hall, he

45 Interview with a Highways Department official, 3 Feb. 2000. In Sept. 2000, for example, he checked the conditions of all the trees planted along the 80 kilometre highway between Suphanburi and Bangkok (KS, 16 Sept. 2000).

46 Interview, 11 Dec. 1999.

47 Personal observation and interview, 25 Apr. 2002.

48 KS, 16 Jan. 2002.

49 Interview with an official from the Provincial Office of Archaeology, 20 Apr. 2000; see also various copies of $K S$ issued during this period. 
called a meeting with officials in charge every two months. ${ }^{50}$ Each meeting of this sort is typically preceded or followed by Banharn's thorough inspection of ongoing construction or renovation works. If there is any discrepancy between the contents of a submitted report and what he sees firsthand, he demands a satisfactory explanation from civil servants in charge.

Banharn makes it a point to call a meeting whenever any matter that concerns Suphanburi comes up. For example, as soon as former Japanese Finance Minister Kiichi Miyazawa announced that Japan would extend a multi-million-baht loan package, the so-called Miyazawa Fund, to Thailand in 1999, Banharn called a meeting with high-ranking civil servants to discuss specifically how the fund was to be allocated and used by all the relevant offices in Suphanburi. ${ }^{51}$ Banharn also calls meetings to discuss matters that civil servants regard as unimportant. In July 1997, for instance, he oversaw a gathering of some 100 local civil servants, including all the District Chiefs and municipality Mayors, just to lecture them on the need to 'maintain the cleanliness, neatness, and beauty of roads at all times'. ${ }^{52}$ To Banharn, however, such meetings are serious enough to justify assembling many civil servants.

Since his election to Parliament in 1976, Banharn has mobilized local civil servants to conduct numerous inspections and meetings of the kind described above in the image of a strict and meticulous longju. Between 1976 and 2002, he conducted a total of 872 such routine checks in all the ten districts of Suphanburi. In 1999, the number reached 102 , or a monthly average of more than eight. ${ }^{53}$ Banharn's reputation as a nit-picking longju-administrator has thus been disseminated and perpetuated.

A civil servant in neighbouring Saraburi province drew an informative contrast between Banharn and Pramarn Adireksarn, a former military general who, until his retirement from politics in 1996, had been continually elected as Saraburi's MP. On the surface, the two MPs appear similar in several respects. They are of roughly the same age, and Pramarn used to be the leader of the Chart Thai Party (1975-88), so he and Banharn have interacted for several decades. Also, Pramarn had held the same number of Cabinet posts as Banharn. Additionally, both have business backgrounds. For all these similarities, however, the two politicians differ considerably in leadership styles. According to my informant, Pramarn, who was educated abroad, is 'a modern manager' who believes in the functional specialisation of bureaucratic duties. As such, he came to Saraburi trusting local civil servants on all levels to perform their respective duties according to their own plans. In sharp contrast, Banharn is a compulsive longju or 'a total manager' (the informant's own translation) who must stick his nose into everything and personally see to it that civil servants in 'his' Suphanburi behave the way he wants. ${ }^{54} \mathrm{He}$ does not give civil servants a free hand.

50 Provincial Office of Suphanburi, Thiraluek phithi pert Phraborom Rachanusawri Phrabat Somdet Phra Junlajomklao Chaoyuhua lae Sala Klang Jangwat Suphanburi [Commemorating the opening of King Chulalongkorn Monument and the Provincial Hall of Suphanburi], p. 41.

$51 K S, 16$ Apr. 1999.

52 KS, 16 July 1997.

53 Author's research based on KS, supplemented by Thin Thai and Suphanburi Sarn, two local papers that were in print in the 1980s. Since the library holdings of $K S$ consulted are incomplete in some years, the actual number of inspection tours and meetings conducted by Banharn is most likely much higher than the one given here.

54 Interview, 13 Dec. 1999. 
Cynics might dismiss Banharn's leadership as a political 'show' designed to make him look good. Such an interpretation is not wrong; politics always has a thespian quality to it. However, the sheer frequency with which Banharn has come to Suphanburi to supervise local civil servants can actually be viewed as an indication of his truly thorough nature. If his longju-style leadership is a purely deceitful, dramaturgical act of a cunning politician, there is little denying that very few Thai politicians have put so much energy into keeping up that symbolic act as consistently and for as long as Banharn has. He does not do it just before elections. In this respect, it is worth noting that Banharn resides in Bangkok. This means that to start inspecting a given construction site at 7:00 a.m. (which is common), he has to wake up before 6:00, given that it takes one hour to travel from Bangkok to Suphanburi. After a day of inspections and meetings, he returns to Bangkok in the evening or at night, and the following morning he appears in Suphanburi again.

\section{Civil servants' view of Banharn's meticulousness}

Many civil servants in Suphanburi deeply resent Banharn's nit-picking style of control. As I have observed, only a small number of high-ranking civil servants, who owe their current positions to Banharn and have a good chance of further promotion in the near future, eagerly and sycophantically follow his leadership. Many others, however, refer to Banharn as a longju in a pejorative sense to vent their frustration at his excessive meticulousness and unwanted interference in their jobs. ${ }^{55}$

There are a few simple mundane reasons for their dislike of Banharn's leadership. First, it is extremely tiring and burdensome to follow Banharn, both literally and figuratively. Since he conducts many inspection tours and meetings from morning until evening, and often on weekends, civil servants hardly have any time to relax at home with their families. As one civil servant said, 'Of all the civil servants in Thailand, I bet that those in Suphanburi are the most tired. You work here for one year, and you will look ten years older! ${ }^{56}$ Another civil servant said with reference to former Governor Wiphat Khongmalai (1998-2003): 'Wherever Banharn goes in Suphanburi, Wiphat has to go there.... In other provinces, the Governor sits back behind the desk and gives orders. In Suphanburi, the Governor's job is to be outside, following Banharn and taking his orders. ${ }^{57}$ Additionally, since civil servants accompany Banharn 'voluntarily' outside of their regular working hours as part of their self-imposed official duties, they are not paid for this 'excessive overtime work'. Still another civil servant said: 'They say Japanese workers are workaholics. But Suphanburi's civil servants work just as long. The difference is that it is in the nature of the Japanese to work hard, but we are forced to be hardworking. ${ }^{58}$ The usual image of well-connected civil servants in late-developing countries is that they are lazy. In present-day Suphanburi, however, the need to remain in Banharn's favour pushes them to be extremely diligent; they cannot afford to relax.

55 Banharn's style has caused friction with, and estranged, other CT Party MPs too. One is his own brother Chumpol, who resigned as Education Minister in 1998 because of Banharn's 'constant interference'. According to one civil servant in Suphanburi, Chumpol, who has an MA in public administration from an American university, has 'a modern head' and is not accustomed to Banharn's 'traditional type of administration' (Interview, 2 Apr. 2000).

56 Interview, 7 Dec. 1999.

57 Interview, 30 Jan. 2000.

58 Interview, 6 May 2002. 


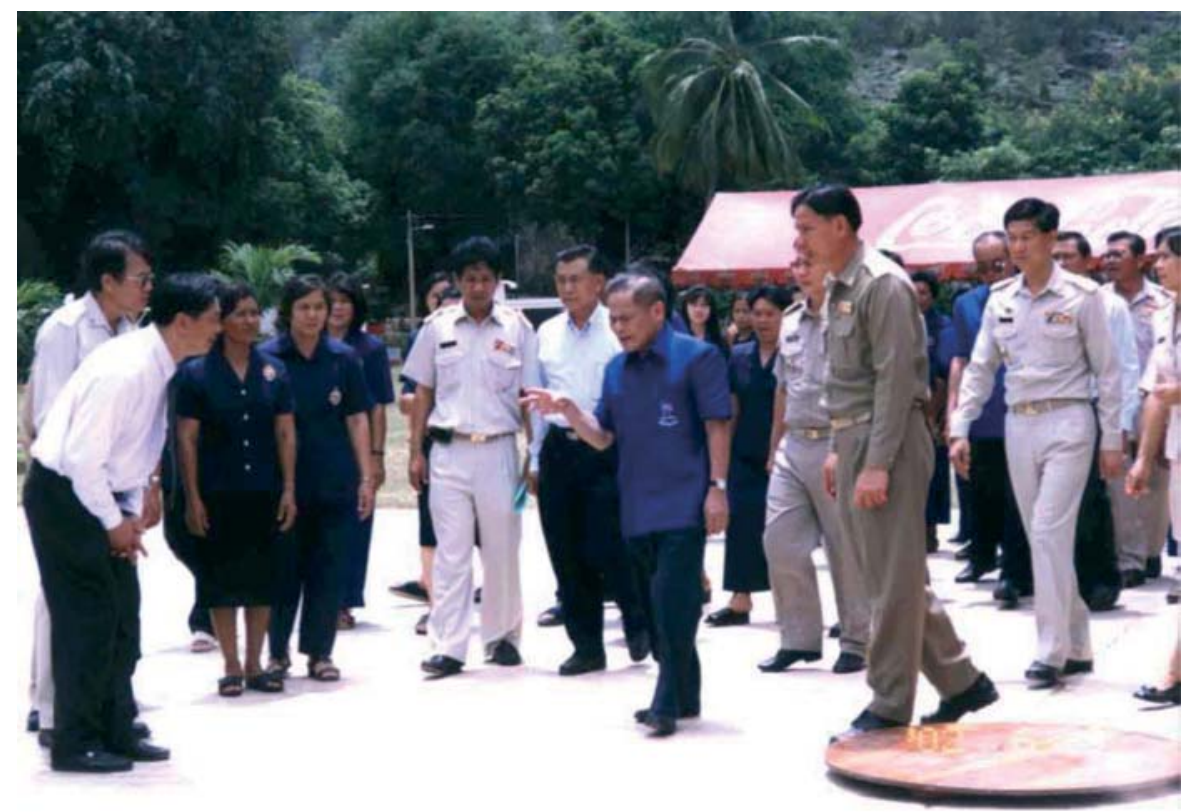

Figure 3 Banharn giving an order to a civil servant (photo by the author, June 2002)

Second, many civil servants find Banharn's leadership insulting, for they must put up with a barrage of overbearing acts (such as finger-pointing) and harsh words Banharn relentlessly levels at them in public. In Thailand such behaviour is particularly unbearable. One civil servant said: 'Pointing your finger at someone is not part of Thai manners, but Banharn does it all the time without thinking about the feelings of others. ${ }^{59}$ I myself have seen him do such finger-pointing many times (see Figure 3).

A few civil servants recounted one episode that indicates how mortifying it is to bear Banharn's fastidiousness and his outbursts of anger. In 1999, he inspected the newly constructed Provincial Hall. During this inspection, he walked into one of the toilets, and saw that its wall had been painted in a colour different from the one he had requested. He then lashed out at the accompanying contractor, and ordered him to replace the wall with a brand-new one at the company's expense. After Banharn left the scene, the contractor, a man over 50 years old, wept in public, with many civil servants present sympathizing in silence. To these people, the colour of the wall in a toilet was too trivial a matter to justify Banharn's unreasonably harsh words and punishment. ${ }^{60}$

Put in the broader historical context of Thai politics, Banharn's fussy longju-style control symbolizes a dramatic reversal of the relative power relationship between civil servants and politicians. In the heyday of the bureaucratic polity, civil servants enjoyed higher social status. Politicians had to curry favour with them to obtain particular favours from the state. Now the very opposite holds true in Suphanburi. Civil servants have been completely subordinated to Banharn. Since Banharn is a very short man 
(barely $150 \mathrm{~cm}$ ), the act of civil servants stooping down to talk to him accentuates their humiliating subservience all the more.

Banharn is actually aware of the presence of civil servants who hate his extreme meticulousness, but ultimately he does not seem to care about what they think of him. ${ }^{61}$ Their 'hidden transcripts', to use James Scott's terminology, are not his concern. ${ }^{62}$ What he cares about is their public behaviour. As long as they do what he wants them to do such as tag along with him in inspection tours, attend meetings and submit reports - he is not interested in whether they do so eagerly or grudgingly. And that is exactly what civil servants choose to do. Not doing so could cost them their posts or funds. They have no other choice. Banharn's institutional power has created an authoritarian bureaucratic culture at the provincial level within a (nominally) democratic setting at the national level.

Exacerbating the eager or reluctant obeisance of civil servants is the presence of their predecessors who have achieved rapid promotions thanks to their (public) loyalty to Banharn. These predecessors have set powerful examples for other civil servants to follow. One example is Winit Benjaphong, Suphanburi-born former Director of the Regional Office of Highways Department (1988-95), who accompanied Banharn on numerous inspections, and methodically carried out various construction projects, such as enhancing the aesthetic qualities of roads in accordance with Banharn's wishes. In 1995, then Prime Minister Banharn rewarded Winit by appointing him Deputy Director-General of the Bangkok-based Department of Highways. ${ }^{63}$ Another example is Aree Wong-araya, the former Governor of Suphanburi (1984-88) who served as Deputy Permanent Secretary and Permanent Secretary of the powerful Interior Ministry between 1988 and 1996. While Suphanburi's Governor, Aree had cultivated intimate ties with Banharn by accompanying him on virtually every occasion. As one civil servant jokingly recalled, 'Wherever Banharn was, Aree was there. Aree's secretary didn't have to have his daily schedule to know where he was; all she had to know was Banharn's schedule. ${ }^{64}$

Whether these and numerous other civil servants were genuinely loyal to Banharn is unknown. What is certain, however, is that when they were in Banharn's presence, they followed his leadership ingratiatingly without showing any sign of resentment, and for that they were amply rewarded. The presence of these people serves as 'irrefutable' reminders to their successors that administrative competence still takes a back seat in bureaucratic promotions. Civil servants who desire to advance or protect their present careers therefore have an incentive to tolerate Banharn's fussy leadership and even to pretend that they enjoy following it. In order to maximize their individual career interests, they force themselves to do what they would otherwise regard as too demeaning for their high social status as 'the King's servants' (as bureaucrats are called in Thai).

Similarly, a handful of construction companies have reaped handsome profits thanks to their closeness to Banharn, thus setting powerful precedents for civil servantscum-contractors. One such company is Thawon Suphanburi Limited Partnership,

61 Chart Thai Samphan, 13 (2001): 17, 18.

62 James Scott, Domination and the arts of resistance: Hidden transcripts (New Haven: Yale University Press, 1990).

63 Interview, 5 Feb. 2000.

64 Interview, 12 Dec. 1999. They even played badminton, Banharn's favourite sport, together many times. See KS 25 Jan. 1986; 1 Aug., 1 Sept. 1989; 1 Feb. and 16 Apr. 1990. 
owned by Thawon Jamper-ngern, President of the Sanamchai Sub-district Administration (1996-present). Thawon served as Vice Chairman (1995-96) and chairman (19972001) of the Association of Suphanburians, of which Banharn is the President. He also belongs to the Sports Association of Suphanburi and the Suphanburi Chamber of Commerce, both of which are led by Banharn. Thanks presumably to these ties, Thawon Suphanburi won 324 road construction projects worth over 350 million baht between 1997 and 2002. ${ }^{65}$ Whether Banharn actually helped the company is unknown. But other civil servants-cum-contractors believe that he did, and choose to follow his unwanted supervision in their quest for profits.

Thus, many civil servants in Suphanburi end up helping Banharn enforce his leadership, which they resent. What is significant about this ironic yet highly pragmatic act is that when performed repeatedly day after day, week after week, month after month, and year after year, following Banharn's leadership becomes a habit on the part of civil servants. To draw on Foucault, in the ritualistic act of forcing themselves to do what they do not want to do again and again, civil servants are constantly and acutely made to realize and instil in their bodies Banharn's close surveillance sustained by his enormous appointive and budgetary power in the central state. They are made to internalize and magnify 'thousands of (Banharn's) eyes' that maintain 'permanent, exhaustive, omnipresent surveillance' over their behaviour and every stage of every development project in every part of Suphanburi. ${ }^{66}$ This actual or imagined surveillance in turn serves, paradoxically enough, to drive civil servants to keep putting on acts of public or bodily dissimulation, or what Lisa Wedeen calls 'a politics of "as if" in following Banharn's leadership all the more. ${ }^{67} \mathrm{~A}$ self-perpetuating process is at work here. One civil servant made a seemingly simple yet revealing remark: 'I wish I didn't have to go to all the inspection tours and meetings. I'm too tired. But I still have to go. Banharn would know if I don't show up, and I would be transferred to Yasothon [a far-flung poor province near Laos and Cambodia].'68 This statement captures how the bodies of local civil servants have been 'disciplined' to do what Banharn wants.

\section{Banharn's leadership and the Suphanburi populace}

While many civil servants hate Banharn's fussy leadership, ordinary Suphanburians embrace it. To many villagers, his leadership has brought formerly unimaginable benefits. An outstanding example concerns the construction of a school in Ta Pherm Khi, a remote village in Dan Chang district in 1998. Located in a mountainous area near the border with Uthai Thani province and some 190 kilometres away from central Muang district, this village, inhabited by 201 Karen from 41 families, had long been the poorest village in Suphanburi. The level of education attained by its residents was also the lowest since the village did not have a primary school. ${ }^{69}$ In November 1998 Banharn paid a visit to this village. His subsequent action was extraordinarily swift. He called Dilok

65 Department of Business Development, Ministry of Commerce [hereafter DBD/MC], Suphanburi Limited Partnership File No. 198.

66 Michel Foucault, Discipline and punish: The birth of the prison (New York: Vintage Books, 1995), p. 214.

67 Lisa Wedeen, Ambiguities of domination: Politics, rhetoric, and symbols in contemporary Syria (Chicago: University of Chicago Press, 1999).

68 Interview, 31 Jan. 2002.

69 KS, 16 June 1998. 
Phatwichaichoot, then Head of the Provincial Office of Primary School Education, and ordered him to build a new primary school with four classrooms in this village within 72 hours. Since this order came out of the blue, Dilok did not have enough construction funds. To overcome this problem, Banharn told him to get the construction materials by dismantling one no-longer-used building at Wat Makham Tao School in neighbouring Derm Bang Nang Buat district. As a provincial longju, Banharn knew exactly which school buildings were no longer used and where they were located. Then he ordered the Provincial Council and the Provincial Offices of Highways and Accelerated Rural Development to provide manpower and trucks for transporting the dismantled materials to Ta Pherm Khi over a distance of some 60 kilometres. As road construction agencies, the latter two civil service offices actually have nothing to do whatsoever with school construction, but Banharn's appointive and budgetary power allowed him to mobilize their human and material resources smoothly without being fettered by any ponderous bureaucratic red tape. On Banharn's behest, Dilok hired 53 workers who undertook the construction of the new school on three shifts.

Thanks to this round-the-clock work that entailed the mobilization of numerous civil servants and workers, the construction of the first school in Ta Pherm Khi was completed in just 59 hours. ${ }^{70}$ Having followed Banharn's leadership for a long time, the civil servants had by this time been 'habituated' to supply a development good within the strict time limit he imposed, and his physical presence was not necessary to maximize bureaucratic efficiency. Ta Pherm Khi residents were extremely pleased with the results. This news, sensationally reported in the provincial newspapers and also spread by word of mouth, also impressed many people elsewhere in Suphanburi. A reporter for Khon Suphan expressed their amazement and admiration when he wrote: 'Many people must be speechless. How could they build a school in three days when it takes at least four to five days just to build a tiny house? ${ }^{71}$

Another benefit of Banharn's leadership that ordinary Suphanburians mention is less bureaucratic corruption. Since Banharn so closely monitors all local development projects, otherwise dishonest civil servants cannot expect to get away with cutting corners. As one official from the Highways Department said, 'Banharn owns a construction company himself, so he can tell immediately if any substandard materials are being used. He knows all the tricks of the trade. You can't fool him. ${ }^{.72}$ Banharn illustrated this point himself by drawing a contrast between Suphanburi and Nakhon Sawan province: 'Go and look at the road from Nakhon Sawan to Tak. It is very bad. It has completely crumbled. They have to build it all over again at a cost of 1,000 million baht. It is a waste of money. ${ }^{73}$ The implication is that Nakhon Sawan's MPs fail to monitor local

70 KS, 16 Dec. 1998. While Head of the Provincial Office of Primary School Education (1996-2000), Dilok directed the construction of many other schools to Banharn's satisfaction. In 2000, Banharn rewarded Dilok by having him appointed as Deputy Director-General of the Bangkok-based National Office of Primary School Education. At that time, Banharn had a stranglehold on the Education Ministry. The Minister of Education was his protégé and MP from Ang Thong, Somsak Prisananandhakul, and Banharn's daughter Kanchana was Deputy Minister of Education.

71 KS, 16 Jan. 1999.

72 Interview, 3 Feb. 2000. Banharn owns Saha Srichai, a Bangkok-based construction company established in 1953 (DBD/MC, Bangkok Company File No. 3893).

73 Chart Thai Samphan, 13 (2001): 17. 
development work, allowing unscrupulous civil servants and contractors to siphon off huge profits for doing shoddy jobs.

In Suphanburi, by contrast, Banharn demands that all projects meet the high standards he has set, allowing little room for bureaucratic corruption and inefficiency. Consequently, state funds, as a good number of ordinary Suphanburians say, reach the village level in full without being devoured by rapacious civil servants and their colluders along the way. Thus, interestingly enough, Banharn, a man who is typically dismissed by Bangkok-based scholars and journalists as a parasite preying on juicy local development projects, is thought by many (if not all) villagers to serve as a vital human brake on otherwise rampant corruption in Suphanburi. Far from engaging in corruption, Banharn is believed to be doing the best he can to minimize it and to supply various development goods in the most efficient manner. His omnipresent longju-style leadership, displayed so frequently in what Clifford Geertz might call the provincial 'theater state' of Suphanburi with numerous civil servants as the grudging supporting cast, conjures up that positive image. ${ }^{74}$

This image explains why many villagers go over the heads of civil servants and approach Banharn directly to request that particular development projects be implemented. For example, when he visited a small village in Song Phi Nong district near Kanchanaburi province in 2002, one middle-aged female villager walked up to him deferentially with a handwritten letter. Banharn stopped to ask her, 'What is this?' She replied, 'I would like you to build a road in our village. It is very inconvenient for us now ...'. After exchanging a few more words with the villager, Banharn put the letter in his pocket. ${ }^{75}$ I do not know whether or how he has responded to the villager's plea since then, but this incident indicates the extent to which ordinary Suphanburians regard local civil servants as unreliable and have accordingly come to rely on a powerful and 'honest' leader like Banharn to mobilize civil servants for the efficient delivery of desired local development goods.

As a result of Banharn's close supervision, which allows little bureaucratic corruption, Suphanburi has come to possess a variety of high-quality assets that distinguish it from many other provinces - the third major benefit of his meticulous leadership. The most notable examples are the roads, most of which are made of superior materials that are resistant to developing bumps and holes. In 1968 Suphanburi had only one surfaced highway of 79 kilometres in length. Now, the province has 59 asphalted and concreted highways with a combined length of 1,942.5 kilometres. Suphanburi accounts for 24 per cent of all the asphalted and concreted highways in the nine provinces of Central Thailand. Moreover, in terms of length of asphalted and concreted feeder roads, Suphanburi is ranked third among the 75 provinces of Thailand. ${ }^{76}$ Consequently, it has come to be nationally famous for the exceptional durability and smoothness of its roads. The roads there have also become nationally renowned for their aesthetic qualities. To satisfy

74 Clifford Geertz, Negara: The theater state in nineteenth-century Bali (Princeton: Princeton University Press, 1980), p. 13.

75 Personal observation, 3 June 2002.

76 Untitled data obtained at Departments of Highways, Accelerated Rural Development and Public Works. 
Banharn's penchant for beauty, cleanliness and tidiness, civil servants go to great lengths to sweep the roads, trim the trees, water the flowers and keep the grass lush. ${ }^{77}$

Many other development goods are of equally high quality. For example, the Provincial Stadium, renovated between 1990 and 1994 with a fund of 27.5 million baht, boasts of having facilities that are good enough to have hosted many international sports competitions, including the Asian Games of 1998. Only seven other provinces in Thailand have stadiums of comparable size and quality. Another example is Chaophraya Yommarat Hospital, which Banharn has expanded since 1976 into one of the largest and the most modern hospitals in Central Thailand with a fund of over 686 million baht. ${ }^{78}$

Furthermore, many schools have also come to be known for their appearance as they are decorated with beautifully trimmed trees and colourful flowers. Many teachers also take assiduous care to keep their schools rubbish-free. For example, in preparing for Banharn's visit in 2002, several teachers at Wat Phonsawan School scurried around the playground, picking up rubbish with their hands. When picking up a tiny cigarette butt, one teacher said to the villagers and me standing nearby: 'Mr. Banharn wouldn't be happy if he saw this.' In the words of one former schoolteacher, all the schools in Suphanburi are virtually forced to 'compete in the province-wide beauty school contest' organized by Banharn. ${ }^{79}$ This is no laughing matter for the schoolmasters who must take the brunt of Banharn's scolding if they do a poor job of beautifying their schools. To give one extreme example, one schoolmaster recently died in office, and his former subordinates believe it was due to the severe stress of having worked under Banharn for several months in a row. ${ }^{80}$

To be sure, one major reason for the appearance of many of these projects is the massive infusion of state funds that Banharn controls. But his personal and direct supervision is equally important. A handful of other provinces ruled by influential MPs, such as the aforementioned Pramarn Adireksarn of Saraburi and Newin Chitchob of Buriram, have received just as much public funding, yet these provinces have few projects that can match Suphanburi's. This disparity can be explained by Banharn's uniquely meticulous administration. Many of my respondents illustrated the value of Banharn's leadership by contrasting him to other 'bad' MPs, notably Chuan Leekpai, the former leader of the Democrat Party who is widely regarded as one of the most honest politicians in Thailand. A mechanic in Muang district made a typical remark:

Once Banharn implements a project in Suphan, he makes it a point to come back to Suphan to check up on its progress every week, until the day it is completed to his satisfaction. He takes a direct interest in every project. He never abandons it. What does Chuan do? ... He lets irresponsible and corrupt local officials take full charge. He seldom goes back to

77 Bangkok Post, 25 Sept. 1995.

78 BB, Ekasarn ngop-pramarn 2533 (hereafter EN), 4, 5: 333, EN 2535, 4, 5: 331, EN 2536, 4, 5: 362, and EN 2537, 4, 5: 393; Sports Authority of Suphanburi, Thiraluek phithi wang silarert arkhan thiphak nakkiilaa khanat 200 tiang jangwat Suphanburi [Commemorating the cornerstone-laying ceremony for athletes' hostel with 200 beds, Suphanburi] (Suphanburi: NP 1998), p. 14; KS, 30 July 1976, 1 Feb. 1990; BB, EN 2520, 3, 7: 53, 68, EN 2540, 4, 9: 293, 379, EN 2544, 4, 9: 67; Chaophraya Yommarat Hospital, Thiraluek phithi pert tuek khon khai phiset Banharn-Jaemsai Silpa-archa 3 [Commemorating the opening ceremony for Banharn-Jaemsai Patients' Ward 3] (Suphanburi: NP 1998), pp. 33, 38.

79 Personal observation, 3 June 2002; interview, 17 Dec. 2000.

80 Anonymous interviews, 19, 30 Jan. 2002. 
Trang [Chuan's home province] to inspect local projects. Of course, the level of Suphan's development is superior to Trang's. ${ }^{81}$

Similarly, according to another respondent, a former hospital worker, Banharn is willing to exhaust himself for his hometown, which he loves so much. But Chuan is too inactive. He sits in an air-conditioned office and tells his subordinates to do jobs for him.' ${ }^{82}$

A few media reports add credibility to these impressionistic views. For example, Villagers in Deep Trouble, a daily TV programme, once featured villagers from Trang who complained about an un-surfaced road in their community: 'Our MPs have disappeared as soon as they got elected. We haven't seen their faces since the election [of 1996].' ${ }^{83}$ This type of comment is never heard in Suphanburi, where people have a chance to see Banharn mobilizing civil servants to undertake local development virtually every week. On another day, the same TV programme reported that in the Provincial Council election of February 2000, only nine out of 500 eligible voters in one village of Trang cast their votes. The rest boycotted the election in silent protest against the incumbent Provincial Councillors and MPs who, despite villagers' repeated and desperate pleas in the last two decades, had not kept their promise to bring electricity to their village. ${ }^{84}$ Again, such longstanding neglect and local grievances is rarely heard in Suphanburi, where most people hail Banharn as a hardworking developer who takes quick and decisive action in ameliorating their difficulties.

Last but not least, many Suphanburians are happy at a personal level about seeing Banharn reprimand civil servants. The accounts of officials treating local people contemptuously, especially farmers, are well known. It is not uncommon at all, as Ruth $\mathrm{McVey}$ reminds us, for civil servants to despise, humiliate, or even ignore farmers simply because they are poorly dressed and do not speak standard Thai ${ }^{85}$ Against such a social backdrop, the sight of Banharn, a tiny and poorly educated native of Suphanburi, lording it over taller and better educated civil servants appointed by Bangkok, provides a certain amount of satisfaction. A petty merchant in Muang district made what is a typical comment:

I get emotionally vindictive satisfaction ( $s a-j a i)$ when I see Banharn scold civil servants who normally act haughtily toward us. They can't say anything in his presence. All they can say is 'yes, yes, yes.' We need a man like him to put them in their place. Otherwise, they wouldn't do their duty. ${ }^{86}$

Thus, while many civil servants detest Banharn's intrusive longju-style leadership as a deep affront to their high social status, that is exactly what ordinary Suphanburians embrace. His leadership has humbled supercilious and unresponsive civil servants, an action from which many Suphanburians derive enormous vicarious delight.

83 ITV, 19 Nov. 1999.

84 ITV, 6 Feb. 2000.

85 McVey, 'Of greed and violence', p. 4.

86 Interview, 18 Apr. 2002. 
Banharn's meticulous leadership has brought a good deal of collective and personal benefits to ordinary Suphanburians. This represents a vast, emotionally gratifying temporal progress from the past, in which civil servants reigned supreme without doing much for local development. Not surprisingly, many Suphanburians applaud Banharn's leadership, with which they are all familiar.

My 170 respondents have personally seen, read about or heard about him supervising local civil servants in one way or another in the last three decades. Out of this constant and frequent exposure to his publicly displayed leadership, many Suphanburians have come to form a very favourable image of him as an indefatigable and uncompromising longju-type provincial manager who pushes otherwise indolent, haughty, irresponsible and inefficient local-level agents of the state to do their jobs scrupulously in the interest of local development; 78 per cent of my respondents, who commented on Banharn's qualities as a politician, cited his strict, meticulous and efficient management of local civil servants as the reason for their support for him. This management explains why so many development projects have come to be provided so swiftly and efficiently. Thus, while scholars and journalists write off Banharn as a politician who is too incompetent to run Thailand, most ordinary Suphanburians see a different politician, one who has governed Suphanburi very efficiently and competently. A columnist for Suphan Post spoke for many Suphanburians when he wrote: 'I had an opportunity to accompany Banharn [on one of his inspection tours]. Having seen him work, I am not surprised that Suphanburi has prospered the way it has. It's all because he takes his duties seriously. ${ }^{, 87}$ Another columnist put it just as succinctly: 'Everything is developing in a good direction' because Banharn is a 'longju'. ${ }^{88}$ Most Suphanburians therefore have a very good reason to appreciate Banharn's meticulousness. Instead of reducing his unchallenged domination at present to violence, intimidation, money, protection and other instruments commonly employed by nakleng-type provincial bosses, it should be seen as the product of his successfully enforced leadership, which reflects his non-nakleng personality.

\section{Conclusion}

I have used the case of Banharn's domination to highlight one type of leadership and domination in provincial Thailand, which the existing literature on nakleng has ignored to date. Banharn does not fit well the image of nakleng-type strongmen who are supposed to predominate in provincial Thailand. Instead, he is a fussy leader, and ordinary Suphanburians like and support him precisely because of this characteristic. Ockey, Pasuk and other scholars who play up the nakleng attributes of provincial leadership fail to recognize that a fussy person can govern his constituency as effectively and for as long as Banharn has done. Some strongmen do have nakleng-type characters, but others, including Banharn, do not. Accordingly, different provincial strongmen have different ways of establishing and maintaining their domination.

Ignoring this simple reality, the existing works on nakleng - precisely because they are so widely read and cited - have contributed immensely to perpetuating a stereotyped image of provincial Thailand as an inferior and problematic category, an entity that is at the mercy of guns, goons, and gold - the chief instruments of domination for nakleng. 
The Orientalist critique that Reynaldo Ileto has made with respect to scholarship on the Philippines can be made about the scholarship on provincial Thai politics, too. ${ }^{89}$ Daniel Arghiros and Michael Nelson do spotlight non-nakleng-type leaders, but to the extent that they play up the salience of vote-buying and other unsavoury means of domination, they, too, inadvertently and unfortunately contribute to deepening the same negative image of provincial leaders. ${ }^{90}$ My case study of Banharn is meant as one attempt to question or challenge this hegemonic image.

Stated a little more concretely, I have highlighted Banharn's fussy leadership by situating it squarely in historical and institutional contexts. Some leaders may want to exercise leadership that reflects their respective personalities, but they may not be able. A desire to enforce a particular type of leadership is one thing, and an ability to do so is another. Furthermore, just because a particular leader is able to enforce his favoured type of leadership, it does not necessarily mean that his subjects will like it. I have therefore focused on the historical and institutional conditions, under which Banharn's fussy leadership has emerged and has come to be viewed as valuable by ordinary Suphanburians.

Specifically, I have shown that the absence of the developmental state led villagers in Suphanburi to deepen the longstanding adverse images of local civil servants. This set the historical context for the much-appreciated rise of Banharn's leadership in the post-1976 period. I have also indicated how the patrimonial nature of the democratic state has enabled Banharn to control local civil servants in the image of a strict and thorough provincial longju. Had he and/or his protégés not held key formal positions, and also had Suphanburi not emerged as a one-party dominant province in this institutional milieu, he would not have been able to impose his meticulous leadership as effectively as he has. A combination of his personality, history and institutions are essential components of his leadership. If any one of them were missing, Banharn would not be able to stay in power in Suphanburi.

By examining the confluence of these three factors, we can also explain why a leader like Banharn has not appeared in other provinces. In the first place, not many leaders, I would venture to guess, are as fussy as Banharn. In fact, many strongmen, such as Pramarn, have quite the opposite personalities. The negative images of local state officials may exist in many provinces besides Suphanburi (as I have suggested above), and some leaders in those provinces might be actually just as fussy as Banharn, but the institutional context in which he operates does not exist. Few politicians have held as many Cabinet posts as Banharn has. In addition, with the exception of Phang-nga, no other province in Thailand is a one-party dominant province.

I propose that scholars of Thai politics explore the multiple types of provincial strongmen's leadership more fully than they have done to date. This seems to be one fruitful agenda of research. To date, relatively little in-depth empirical research has been done on any one provincial strongman. The works on nakleng by Ockey and others give

89 Reynaldo Ileto, Knowing America's colony: A hundred years from the Philippine War (Honolulu: University of Hawaii, Center for Philippine Studies, 1999).

90 Daniel Arghiros, Democracy, development, and decentralization in provincial Thailand (Richmond: Curzon, 2001); Michael Nelson, Central authority and local administration in Thailand (Bangkok: White Lotus, 1998). 
only sketchy and crudely generalized descriptions on the basis of shaky evidence drawn from Bangkok-based media accounts and/or from superficial local-level fieldwork. Based on their extensive fieldwork, Arghiros, Michael Montesano and Nelson give detailed accounts of individual politicians, but these authors focus more on the cultural or social contexts and patterns in which those politicians get elected or have risen politically and economically, rather than on how their personalities are reflected in their everyday leadership styles and how that leadership is perceived by local people..$^{91}$ In addition, the politicians these authors spotlight are not those who can be called 'strongmen' or 'bosses'. Consequently, we still know relatively little about what types of people really govern various parts of provincial Thailand - one lacuna in the current state of research. This stands in contrast to more solid knowledge that we have accumulated with respect to national-level or Bangkok-based politicians. ${ }^{92}$ Much more research could and should be done on individual strongmen who have made it to Bangkok on the basis of their solid bases of support at the provincial level. Newin Chitchob of Buriram, Sanoh Thienthong of Sakaew, Sanan Kachonprasert of Phichit and the late Montri Pongpanit of Ayutthaya, to name just a few, would be quite good research topics. We are in need of solid, empirically grounded work that closely examines the nexus between personalities, historical conditions and institutional contexts with respect to these and many other provincial strongmen. ${ }^{93}$ Such works would hopefully contribute to presenting a more variegated, complex and interesting picture of provincial politics than the one currently available.

91 Arghiros, Democracy, development, and decentralization in provincial Thailand; Michael Montesano, 'The commerce of Trang, 1930s-1990s: Thailand's national integration in social historical perspective' (Ph.D. diss., Cornell University, 1998); Montesano, 'Market society and the origins of the new Thai politics', in Money and power, ed. McVey, pp. 97-122; Nelson, Central authority and local administration in Thailand.

92 See, for example, Thak, Thailand; Duncan McCargo, Chamlong Srimuang and the new Thai politics (New York: St. Martin's Press, 1997); William Warren, Prem Tinsulanonda: Soldier and satesman (Bangkok: M.L. Tridosyuth, 1997); Vichitwong na Pombhejara, Pridi Banomyong and the making of Thailand's modern history (Bangkok: Committee on the Project for the National Celebration on the Occasion of the Centennial Anniversary of Pridi Banomyong, 2001); Kobkua Suwannathat-pian, Thailand's durable Premier: Phibun through three decades, 1932-1957 (Kuala Lumpur: Oxford University Press, 1995); Duncan McCargo and Ukrist Pathmanand, The Thaksinization of Thailand (Copenhagen: NIAS Press, 2005); and Pasuk Phongpaichit and Chris Baker, Thaksin: The business of politics in Thailand (Bangkok: Silkworm Books, 2004).

93 A recent issue of Kyoto Review of Southeast Asia similarly proposes that scholars pay due attention to the importance of leadership types in Southeast Asia. This suggestion, made about national-level politicians, can be extended to the level of local-level politicians, too. See 'Statesman or manager? The image and reality of leadership in Southeast Asia', in Kyoto Review of Southeast Asia, 6 (2005) (http:// kyotoreview.cseas.kyoto-u.ac.jp). 